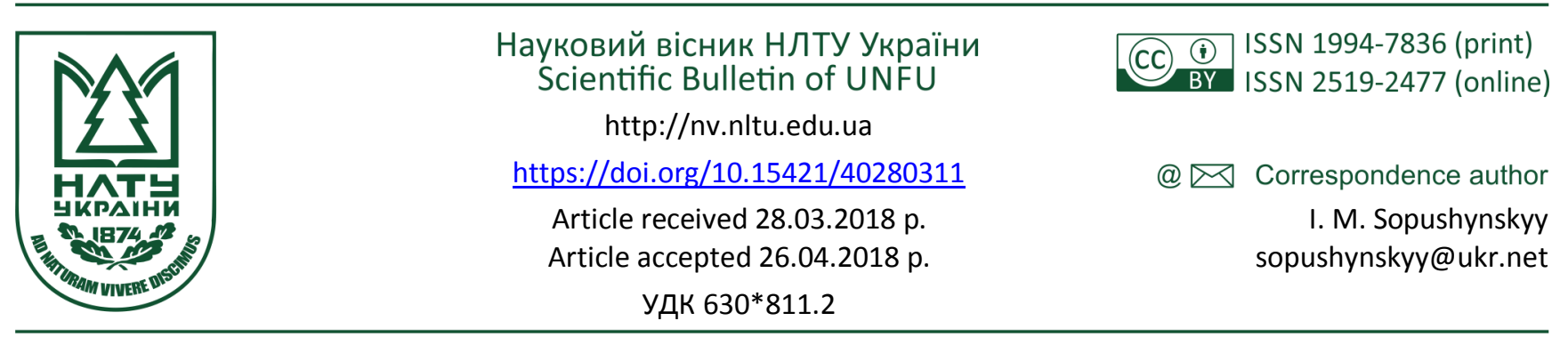

I. М. Сопушинський ${ }^{1}$ Х. Мілітц ${ }^{2}$, Р. Т. Максимчук ${ }^{1}$, В. Біцікс ${ }^{2}$

${ }^{1}$ Національний лісотехнічний університет України, м. Львів, Україна

${ }^{2}$ Геттінтенський університет ім. Георга Августа, м. Геттінтен, Німеччина

\title{
ДИНАМІЧНИЙ МОДУЛЬ ПРУЖНОСТІ ХВИЛЯСТО-ЗАВИЛЬКУВАТОЇ ДЕРЕВИНИ ABIES ALBA MILL.
}

\begin{abstract}
Досліджено відмінності динамічного модуля пружності, коефіцієнта затухання та швидкості звуку хвилясто-завилькуватої деревини порівняно з прямоволокнистою деревиною ялиці білої. Графічно наведено варіацію досліджуваних показників у межах радіуса та висоти стовбура. У межах радіуса стовбура із хвилясто-завилькуватою структурою можна виділити два класи якості деревини, а саме: перший - периферійна деревина (40\% радіуса стовбура) та другий - центральна (ядрова) деревини. Структурне розміщення деревного волокна, зокрема хвилясто-завилькувате, істотно визначає фізико-механічні характеристики деревини та їх варіацію. Коефіцієнт затухання деревини змінюється: від 6 до 10 для хвилясто-завилькуватої деревини; від 12 до 14 для прямоволокнистої деревини. Встановлено прямолінійну залежність першого порядку між динамічним модулем пружності та об'ємною масою деревини. Збільшення об'ємної маси прямоволокнистої деревини зумовлює збільшення модуля пружності та описується рівнянням прямої $\left(\mathrm{R}^{2}=0,69 \ldots 0,72\right)$. Прямолінійна залежність між динамічним модулем пружності та щільністю хвилясто-завилькуватої деревини $є$ інверсійною. Динамічний модуль пружності прямоволокнистої деревини знаходиться в межах від 5921 до $12995 \mathrm{H} \cdot$ мм$^{-2}$, а хвилясто-завилькуватої деревини - від 5053 до $12393 \mathrm{H} \cdot \mathrm{MM}^{-2}$.
\end{abstract}

Ключові слова: ялиця біла; хвилясто-завилькувата деревина; динамічний модуль пружності; об'ємна маса; коефіцієнт затухання.

Вступ. Неруйнівне оцінювання якості деревини є важливою складовою їі механічного сортування, що відіграє важливу роль у дерев'яному будівництві та виробництві конструктивних брусів. Так, більшість наукових праць стосуються вивчення модуля пружності як інтегрального показника механічної якості деревини, метою яких було сортування пиломатеріалів за міцністю деревини на класи якості, в їх основі закладено статичне та динамічне навантаження. Чимало таких робіт висвітлюють питання варіації модуля пружності деревини під час статичного згину та на розтяг вздовж волокон. Показники динамічного модуля пружності деревини є дещо більшими, порівняно 3 аналогічними показниками статичного модуля пружності (Divós \& Tanaka, 2005). Акустичний метод визначення модуля пружності деревини $є$ одним із найкращих неруйнівних методів діагностування вад деревини та дефектів композиційних матеріалів (Zhenbo et al., 2005). Відповідно до теоретичних засад, модуль пружності дорівнює добутку об'ємної маси деревини та квадрату швидкості звуку в деревині вздовж волокон (Bucur, 2006; Vintoniv et al., 2007). При цьому кут нахилу мікрофібрил ранньої деревини впли- ває більше на модуль пружності деревини, ніж пізньої, що пов'язано з його більшою варіацією у ранній деревині річного кільця (Lachenbruch et al., 2010). У деревині більшості хвойних порід встановлено збільшення середнього значення модуля пружності в радіальному напрямку від серцевини до кори (Machado \& Cruz, 2005; Beaulieu et al., 2006). Така закономірність зумовлена збільшенням довжини трахеїд у напрямку від серцевини до периферії стовбура та від комлевої частини стовбура до початку його крони (Mvolo et al., 2015). Перехідна зона між ранньою та пізньою деревиною зумовлює характер зміни щільності деревини в межах річного кільця та відповідно визначає властивості деревини, особливо для швидкорослих хвойних видів (Koubaa et al., 2005). Так, під час застосування резонансного методу для визначення динамічного модуля пружності деревини, кореляція між останнім та статичним модулем пружності деревини є більш прогнозована (Barr et al., 2015). Динамічний модуль пружності кільцесудинної та розсіяносудинної деревини знаходять у прямолінійній залежності від іï об'ємної маси (Chauhan \& Sethy, 2016).

\section{Інформація про авторів:}

Сопушинський Іван Миколайович, д-р с.-г. наук, професор, кафедра ботаніки, деревинознавства та недеревних ресурсів лісу. Email: sopushynskyy@nltu.edu.ua

Мілітц Хольгер, професор, кафедра біології деревини та деревинних продуктів. Email: hmilitz@gwdg.de

Максимчук Руслан Тарасович, аспірант, кафедра ботаніки, деревинознавства та недеревних ресурсів лісу. Email: r.maksymchuk@nltu.edu.ua

Володимир Біцікс, професор, кафедра біології деревини та деревинних продуктів. Email: vbiziks@gwdg.de

Цитування за ДСтУ: Сопушинський І. М., Мілітц Х., Максимчук Р. Т., Біцікс В. Динамічний модуль пружності хвилястозавилькуватої деревини Abies Alba Mill. Науковий вісник НлтУ України. 2018, т. 28, № 3. C. 52-56.

Citation APA: Sopushynskyy, I. M., Militz, H., Maksymchuk, R. T., Biziks, V. (2018). Dynamic Modulus of Elasticity of Wave-Grained Wood of Abies Alba Mill. Scientific Bulletin of UNFU, 28(3), 52-56. https://doi.org/10.15421/40280311 
Мета дослідження - вивчення динамічного модуля пружності прямоволокнистої та хвилясто-завилькуватої деревини в межах радіуса та висоти стовбура Abies alba Mill.

Матеріал і методи дослідження. Для дослідження відібрано 12 модельних дерев ялиці білої з прямоволокнистою та хвилясто-завилькуватою деревиною в Лопушнянському лісництві ДП "Берегометське лісомисливське господарство" (48을 $06^{\prime} 02.34^{\prime \prime}$ пн.ш. $25^{\circ} 13^{\prime} 02.46^{\prime \prime}$ сх.д., 985 м н.р.м.). Взірці деревини розміром $20 \times 20 \times 360 \mathrm{mм}^{3}( \pm 1 \mathrm{mм})$ вирізано в напрямку від кори до серцевини та на висотах 1,3 та 7 метрів. Динамічний модуль пружності визначено на приладі Grindo Sonic кафедри біології деревини та лісової продукції Геттінгенського університету ім. Георга Августа, м. Геттінген, Німеччина в рамках Європейської науково-технічної співпраці "COST Action FP1407: ModWoodLife" (рис. 1).

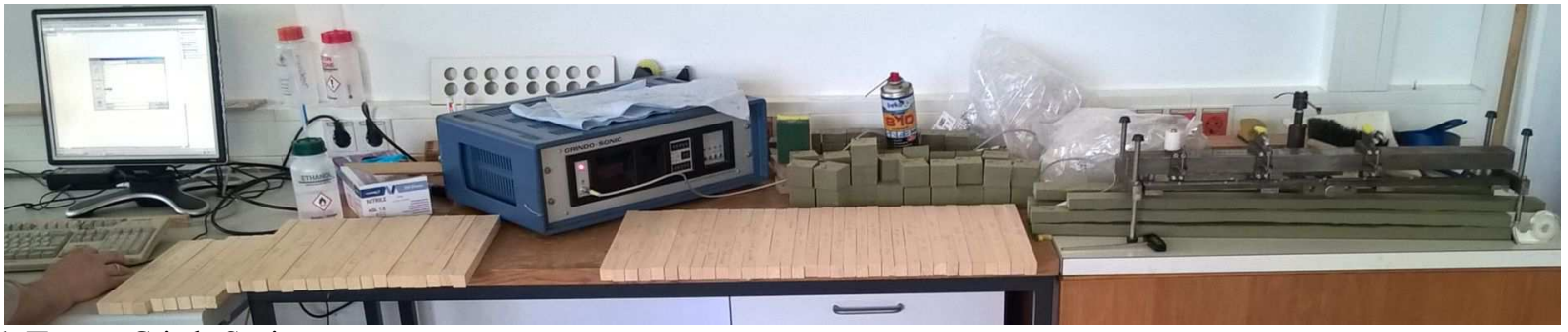

Рис. 1. Прилад Grindo Sonic

В основу методики визначення динамічного модуля пружності закладено повздовжні вібрації. Повздовжній динамічний модуль пружності розраховано за формулою $E_{L}=4 L^{2} f_{\mathrm{m}}{ }^{2} \rho / m^{2}$, де: $L-$ довжина взірця, м; $\rho$ - щільність деревини, кг·м ${ }^{-3} ; f_{\mathrm{m}}$ - повздовжня резонансна частота коливань у деревині, Гц; $m$ - кількість періодів гармонічних коливань. Абсолютна вологість взірців деревини в момент випробування становила $8 \%$. Для визначення середньої швидкості звукової хвилі було проведено три удари молотком (рис. 2).

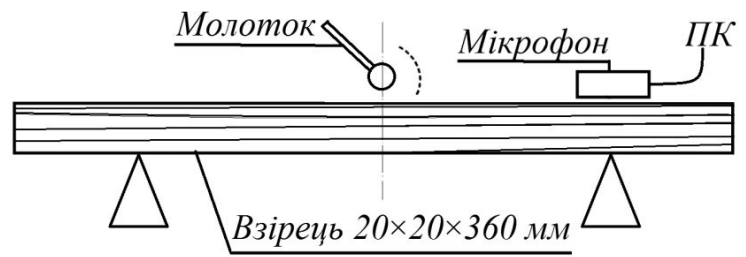

Рис. 2. Схема розміщення взірця деревини під час випробування

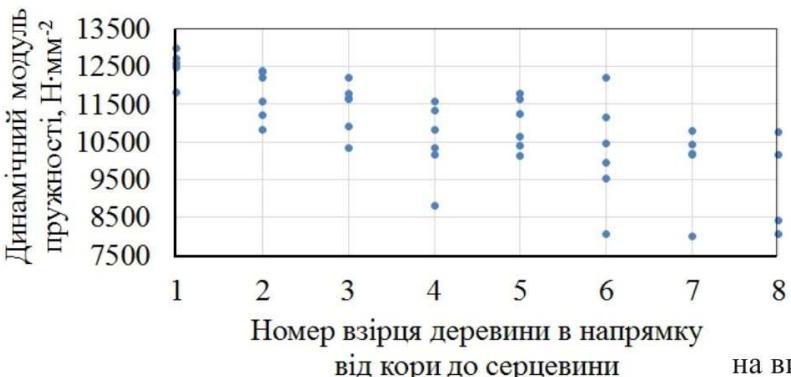
від кори до серцевини на висоті стовбура 1,3 м
Для аналізу резонансних властивостей деревини визначено швидкість звуку (C) та коефіцієнт затухання (К). Взірці деревини виміряно 3 точністю - 0,01 мм та масу зважено - 0,001 г (Vintoniv et al., 2007).

Результати дослідження та їх обговорення. Відмінність властивостей деревини в межах стовбура та між окремими деревами зумовлює вивчення закономірностей формування якісних характеристик деревини як анізотропного матеріалу. Глобальні кліматичні зміни протягом тривалого часу впливають на ріст та розвиток біологічних видів. Такі фенотипічні відміни для деревних видів добре відображаються на межі природного ареалу. Структурні відхилення у деревині, які виявляються через зміну лісорослинних умов, визначають фізико-механічні показники деревини, знання яких $\epsilon$ важливим під час механічного сортування деревини. Зміну величини динамічного модуля пружності в напрямку від кори до серцевини стовбура дерева та за його висотою наведено на рис. 3.
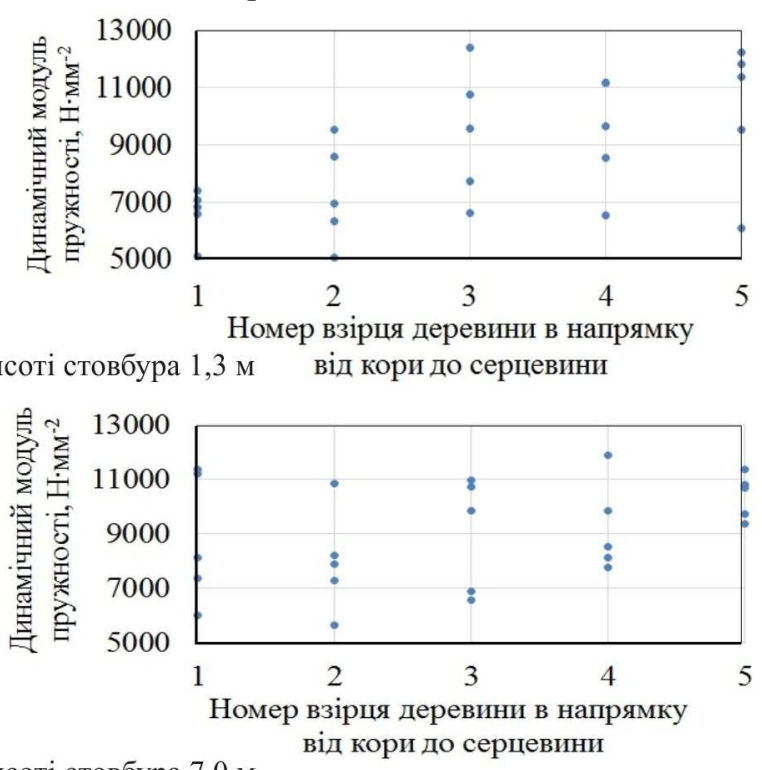

на висоті стовбура 7,0 м б)

Рис. 3. Динамічний модуль пружності прямоволокнистої (а) та хвилясто-завилькуватої (б) деревини ялиці білої

Графічні дані значень динамічного модуля пружності прямоволокнистої деревини свідчать про його плавне зменшення від периферії до серцевини стовбура, що не $\epsilon$ характерним для хвилясто-завилькуватої структури. У межах радіуса стовбура із хвилясто-завилькуватою структурою можна виділити два класи якості деревини: перший - периферійна деревина з низькими показниками динамічного модуля пружності, тобто $40 \%$ радіуса стовбура; другий - 60 \% радіуса центральної (ядрової) деревини, показники якої аналогічні. Для діагностуван- 
ня структурних відмінностей деревини важливим показником $\epsilon$ коефіцієнт затухання звукових коливань (рис. 4).

Як видно з рис. 2, варіація значень коефіцієнта затухання периферійної зони деревини ялиці білої істотно відрізняється. Так, коефіцієнт затухання взірців дереви-

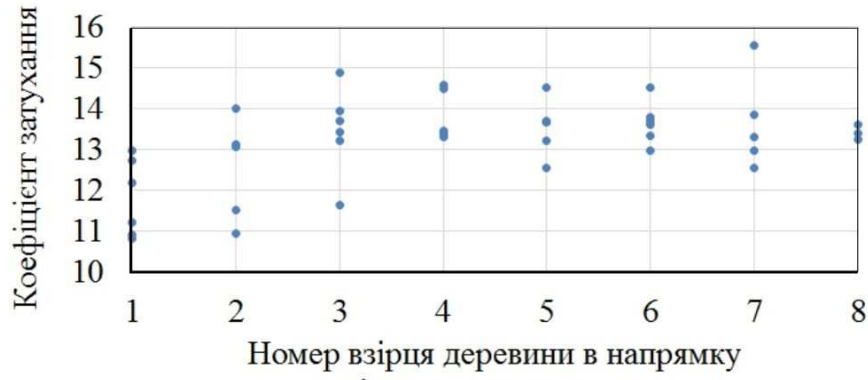

Номер взірця деревини в напрямку від кори до серцевини

на висоті стовбура $1,3 \mathrm{~m}$ ни із хвилясто-завилькуватою деревиною змінюється від 6 до 10, а для прямоволокнистої деревини - від 12 до 14. 3 огляду на це прикладного значення набуває встановлення залежності між динамічним модулем пружності та об'ємною масою деревини (рис. 5).
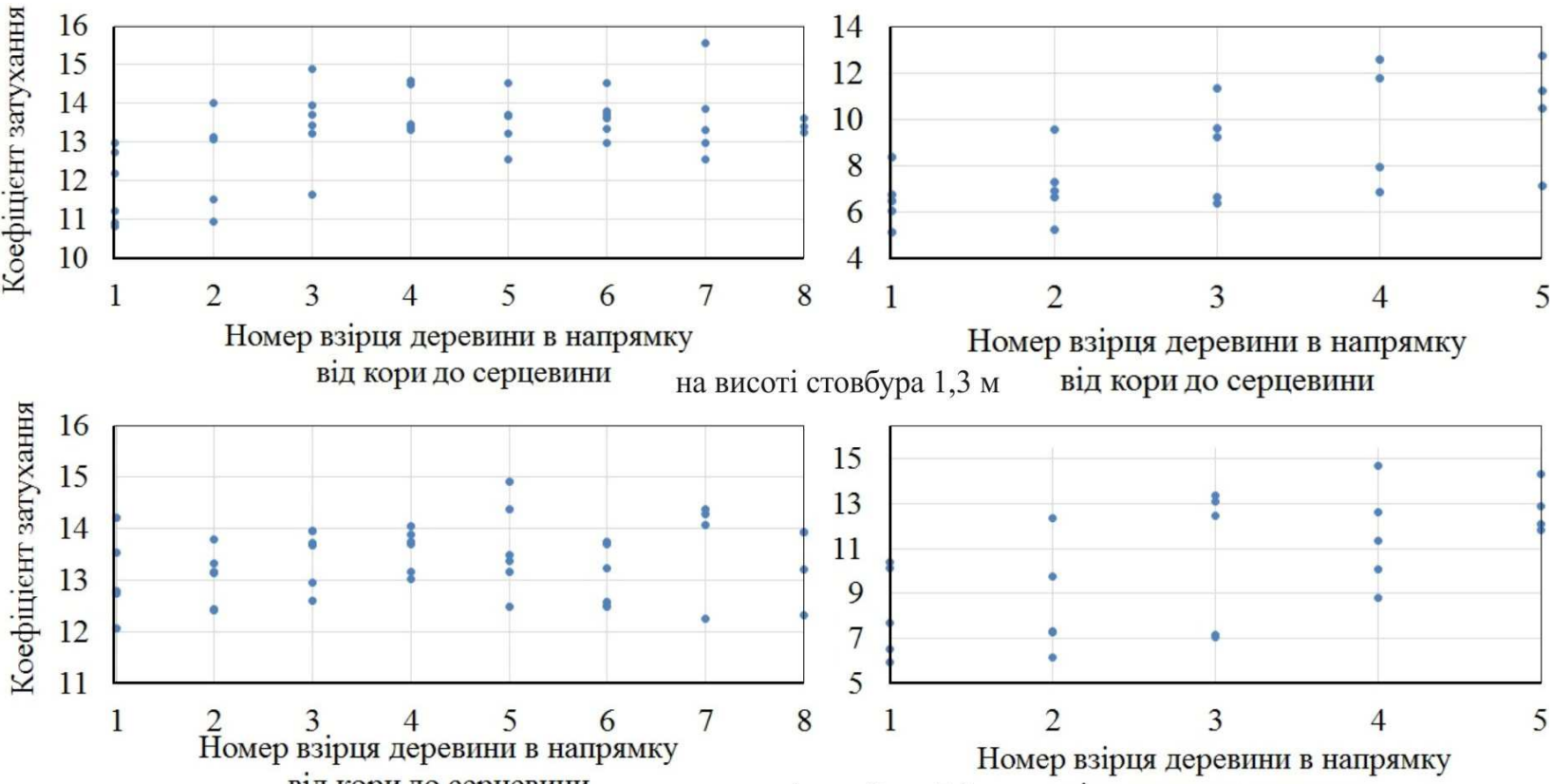

Номер взірця деревини в напрямку

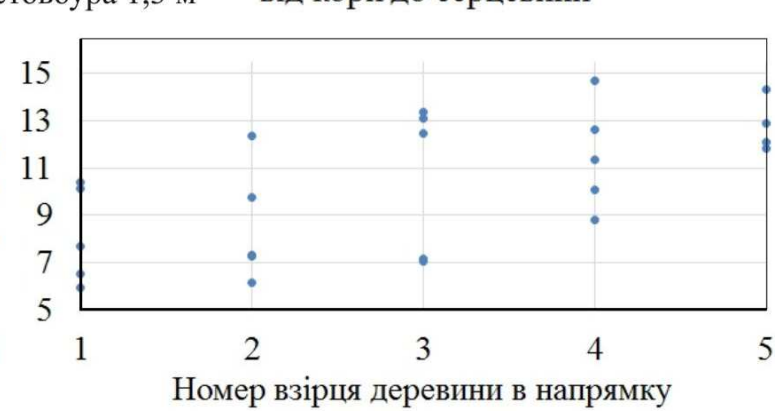
від кори до серцевини

a)

на висоті стовбура 7,0 м від кори до серцевини

б)

Рис. 4. Коефіцієнт затухання прямоволокнистої (а) та хвилясто-завилькуватої (б) деревини ялиці білої
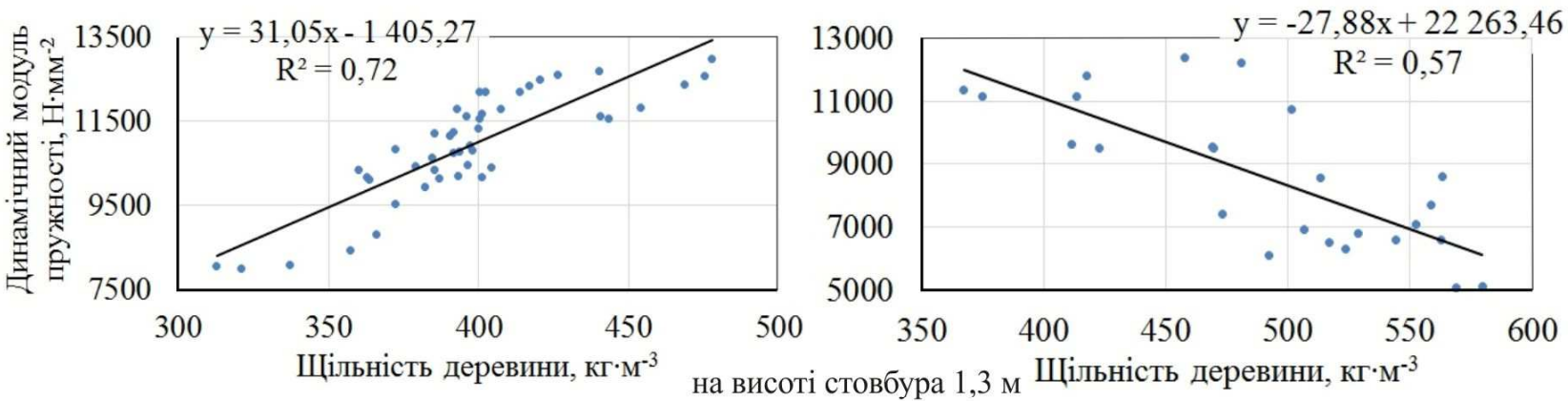

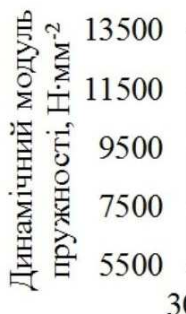

300

$$
y=54,26 x-10709,90
$$

$$
\begin{array}{r}
\mathrm{y}=54,26 \mathrm{x}-10709 \\
\mathrm{R}^{2}=0,69
\end{array}
$$
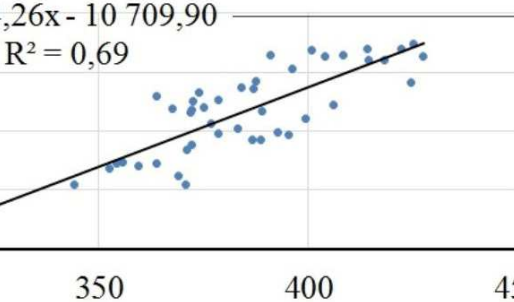

350

400

450

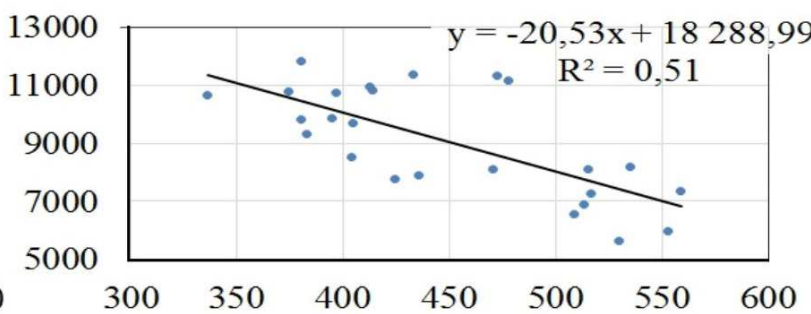

Щільність деревини, кг·м-3

a) б)

Рис. 5. Залежності між динамічним модулем пружності та щільністю прямоволокнистої (а) та хвилясто-завилькуватої (б) деревини

Прямолінійні рівняння залежності між динамічним модулем пружності та щільністю деревини є важливим інструментарієм під час відбору та сортування деревини за якісними характеристиками. Результати дослідження прямоволокнистої деревини свідчать про збільшення модуля пружності із зростанням величини об'ємної маси, що описується рівнянням прямої для взірців деревини на висоті зрізу $1,3 \mathrm{~m}-y=31,05 x-$ $1405,27 \quad\left(R^{2}=0,72\right) \quad$ та 7,0 м $-y=54,26 x-10709,90$ $\left(R^{2}=0,69\right)$. Проте для хвилясто-завилькуватої деревини ялиці білої закономірність має протилежний характер, а зокрема із збільшенням їі щільності зменшується динамічний модуль пружності. Отже, відмінність структурного впорядкування деревного волокна, а саме його хвилясто-завилькувате розміщення, зумовлює зміну закономірності між фізичними та механічними властивостями деревини.

Варіація показників фізико-механічних властивостей деревини $з$ прямоволокнистою та хвилясто-завилькуватою структурою та їх статистична характеристика має прикладне значення для технологічних процесів іiі оброблення (табл.). 
Табл. Статистична характеристика показників фізико-механічної якості деревини ялиці білої

\begin{tabular}{|c|c|c|c|c|c|c|c|}
\hline \begin{tabular}{|c|} 
Висота \\
зрізу \\
стовбура
\end{tabular} & Показник & $\begin{array}{l}N, \\
\text { шт. }\end{array}$ & $\min$ & $M^{ \pm m}$ & $\max$ & $V, \%$ & $\begin{array}{c}P, \\
\%\end{array}$ \\
\hline \multicolumn{8}{|c|}{ Прямоволокниста структура деревини } \\
\hline \multirow{4}{*}{$1,3 \mathrm{M}$} & $E_{L}\left[H \cdot M M^{-2}\right]$ & 45 & 7994 & $10923^{ \pm 191,{ }^{4}}$ & 12995 & 11,8 & \\
\hline & $K$ & 45 & 10,8 & 13,3 & 16,2 & 8,4 & \\
\hline & $C\left[M \cdot c^{-1}\right]$ & 45 & 4858 & $5239^{ \pm 2}$ & 5524 & 3,3 & 0,5 \\
\hline & $\left.\rho_{8 \%[\kappa 2 \times M}\right]$ & 45 & 313 & $397^{ \pm 5}$ & 478 & 8,9 & 1,3 \\
\hline \multirow{4}{*}{$7,0 \mathrm{M}$} & $E_{L}\left[H \cdot M M^{-2}\right]$ & 44 & 5921 & $10134^{ \pm 235,14}$ & 12471 & 15,4 & 2,3 \\
\hline & $K$ & 44 & 12,1 & $13,3^{ \pm 0,10}$ & 14,9 & 5,1 & 0,8 \\
\hline & $C\left[M \cdot c^{-1}\right]$ & 44 & 4352 & 5118 & 5558 & 5,7 & 0,9 \\
\hline & $\rho_{8 \%}\left[\kappa 2 \times M^{-3}\right]$ & 44 & 313 & $384^{ \pm 3}$ & 427 & 6,2 & 0,9 \\
\hline \multicolumn{8}{|c|}{ Хвилясто-завилькувата структура деревини } \\
\hline \multirow{4}{*}{$1,3 \mathrm{M}$} & $E_{L}\left[H \cdot M M^{-2}\right]$ & 25 & 5053 & 8576 & 12393 & 26,8 & $\overline{5,4}$ \\
\hline & $K$ & 25 & 5,1 & 8, & 15,1 & 32,5 & 6,5 \\
\hline & $C\left[M \cdot c^{-1}\right]$ & 25 & 2964 & 419 & 5561 & 19,1 & $\overline{3,8}$ \\
\hline & $\rho_{8 \%}\left[\kappa 2 \times M^{-3}\right.$ & 25 & 367 & 491 & 580 & 12,7 & 2 \\
\hline \multirow{4}{*}{$7,0 \mathrm{M}$} & $E_{L}\left[H \cdot M M^{-2}\right]$ & 25 & 5626 & $9071^{ \pm}$ & 11859 & 20,6 & 4, \\
\hline & $K$ & 25 & 6,0 & $10,5^{ \pm(}$ & 16,7 & 28,8 & 5,8 \\
\hline & $C\left[M \cdot c^{-1}\right]$ & 25 & 3259 & $4527^{ \pm 145,92}$ & 5632 & 16,1 & 3,2 \\
\hline & $\rho_{8 \%}\left[\kappa_{2} \times{ }_{M}{ }^{-3}\right]$ & 25 & 336 & $449^{ \pm}$ & 559 & 14,4 & 2,9 \\
\hline
\end{tabular}

Примітка: $N$ - кількість проведених вимірювань; min мінімальне значення; $M^{ \pm m}-$ середнє арифметичне значення та його помилка; max - максимальне значення; $V$ - коефіцієнт варіації; $P$ - показник точності.

Результати дослідження прямоволокнистої деревини свідчать про те, що іiі середні значення динамічного модуля пружності, коефіцієнта затухання та швидкості звуку є більшими порівняно з аналогічними показниками для хвилясто-завилькуватої деревини ялиці білої. Динамічний модуль пружності прямоволокнистої деревини знаходиться в межах від 5921 до $12995 \mathrm{H} \cdot \mathrm{мm}^{-2}$, а хвилясто-завилькуватої деревини - від 5053 до $12393 \mathrm{H} \cdot$ мм $^{-2}$. Так, середні значення динамічного модуля пружності прямоволокнистої деревини на висоті 1,3 м є на 21,5 \% більшими від аналогічного показника для хвилясто-завилькуватої деревини ялиці білої. При чому щільність хвилясто-завилькуватої деревини за вологості $8 \%$ характеризується більшими середніми значеннями порівняно 3 об'ємною масою прямоволокнистої деревини. Отримані результати досліджень дали змогу встановити істотні відмінності між фізико-механічними характеристиками прямоволокнистої та хвилясто-завилькуватої деревини ялиці білої і визначити залежність між об'ємною масою та динамічним модулем пружності.

Висновки. Результати дослідження динамічного модуля прямоволокнистої та хвилясто-завилькуватої деревини ялиці білої свідчать про таке:

- структурне розміщення деревного волокна ялиці білої визначає діапазон зміни показників динамічного модуля пружності, коефіцієнта затухання та швидкості звуку;

И. М. Сопушинский ${ }^{1}$, Х. Милити ${ }^{2}$, Р. Т. Максымчук ${ }^{1}$, В. Бицикс ${ }^{2}$ ${ }^{1}$ Национальный лесотехнический университет Украины, г. Львов, Украина ${ }^{2}$ Гёттингенский университет им. Георга Августа, г. Гёттинген, Германия

\section{ДИНАМИЧЕСКИЙ МОДУЛЬ ПРОЧНОСТИ ВОЛНИСТО-СВИЛЕВАТОЙ ДРЕВЕСИНЫ ABIES ALBA MILL.}

Исследованы различия динамического модуля упругости, коэффициента затухания и скорости звука волнисто-свилеватой древесины по сравнению с прямоволокнистой древесиной пихты белой. Изучена вариация физико-механических показателей в пределах радиуса и высоты ствола. В пределах радиуса ствола с волнисто-свилеватой структурой можно выделить два класса качества древесины, а именно: первый - это периферийная древесина (40 \% радиуса ствола) и второй - центральная (ядровая) древесина. Структурное размещение древесного волокна, а именно волнисто-свилеватое, существенно определяет физико-механические характеристики и их вариацию. Коэффициент затухания древесины меняется от 6 до 10 для волнисто-свилеватой древесины и от 12 до 14 для прямоволокнистой древесины. Установлена прямолинейная зависимость первого порядка между динамическим модулем упругости и объемной массой древесины. Увеличение объемной массы прямо- 
волокнистой древесины приводит к повышению модуля упругости и описывается уравнением прямой $\left(R^{2}=0,69 \ldots 0,72\right)$. Прямолинейная зависимость между динамическим модулем упругости и плотностью волнисто-свилеватой древесины является инверсионной. Динамический модуль упругости прямоволокнистой древесины находится в пределах от 5921 до $12995 \mathrm{H} \cdot \mathrm{мм}^{-2}$, а волнисто-свилеватой древесины - от 5053 до $12393 \mathrm{H} \cdot \mathrm{мм}^{-2}$.

Ключевые слова: пихта белая; волнисто-свилеватая древесина; динамический модуль прочности; объемная масса; коэффициент затухания.

I. M. Sopushynskyy ${ }^{1}$, H. Militz' ${ }^{2}$, R. T. Maksymchuk1, V. Biziks ${ }^{2}$

${ }^{1}$ Ukrainian National Forestry University, Lviv, Ukraine

${ }^{2}$ Georg-August-University Goettingen, Goettingen, Germany

\section{DYNAMIC MODULUS OF ELASTICITY OF WAVE-GRAINED WOOD OF ABIES ALBA MILL.}

To get deeper knowledge of wood quality as a practical stage of wood grading, which plays an engineering role in wooden construction and production of structural timber, dynamic module of elasticity of wave-grained wood was investigated. The main objective was focused on testing of Silver fir wood with straight-grained and wave-grained structures within stem radius and height. Altogether, 12 model trees were selected in the forest stand of Bukovyna Carpathians with geographical location of latitude of $48^{\circ} 06^{\prime} 02.34^{\prime \prime} \mathrm{N}$, longitude of $25^{\circ} 13^{\prime} 02.46^{\prime \prime} \mathrm{E}$ and altitude of $985 \mathrm{~m}$ asl. Dynamic modulus of elasticity was defined on the Grindo Sonic device of the Department of Wood Biology and Wood Products of Georg-August-Universität Göttingen, Germany within the framework of COST Action FP1407: ModWoodLife. The differences of dynamic modulus of elasticity, damping coefficient and sound velocity between wave-grained and straight-grained wood of Silver fir were estimated. The variation of studied parameters within stem radius and height was graphically analysed. In the stems with wavy-grained wood structure, two wood quality classes were proposed, namely: the first one involved peripheral wood (40\% of the stem radius) and the second one - the central (heart) wood. Wood damping varied from 6 to 10 for wavy-grained wood, and from 12 to 14 for straight-grained wood. The linear relationship between dynamic modulus of elasticity and wood density was estimated. Increasing of wood density caused an increase of the dynamic modulus of elasticity and was described by the linear equation of the first order $\left(\mathrm{R}^{2}=0.69 \ldots 0.72\right)$. The linear relationship between wood density and dynamic modulus of elasticity of wavy-grained wood was inversely proportional. The dynamic modulus of elasticity of straight-grained wood ranged from 5921 to $12995 \mathrm{H} \cdot \mathrm{mm}^{-2}$, and wavy-grained wood - 5053 to $12393 \mathrm{H} \cdot \mathrm{mm}^{-2}$

Keywords: silver fir; wave-grained wood; dynamic module of elasticity; wood density; wood damping. 